\title{
COVID-19: Hyperinflammatory Syndrome and Hemoadsorption with CytoSorb
}

\author{
Behnam Masmouei $^{\text {a }}$ Mehdi Harorani $^{\text {b }}$ Mohammad-Rafi Bazrafshan ${ }^{c}$ \\ Zahra Karimi $^{\text {d }}$ \\ aDepartment of Nursing, School of Nursing Hazrat Zahra (P.B.U.H) Abadeh, Shiraz University of Medical Sciences, \\ Shiraz, Iran; bepartment of Nursing, School of Nursing and Midwifery, Arak University of Medical Sciences, Arak, \\ Iran; 'Department of Nursing, School of Nursing, Larestan University of Medical Sciences, Larestan, Iran; ${ }^{\mathrm{d} C l i n i c a l}$ \\ Nurse, Shiraz University of Medical Sciences, Shiraz, Iran
}

Following the emergence of a novel coronavirus from Wuhan, China, the world faced a major problem, so many countries were shocked by the outbreak of this virus. Unlike the rest of its dangerous family, it has a higher reproductive number than Middle East respiratory syndrome, which is estimated to be approximately 3.28 with a median of 2.79 and IQR of 1.16 [1]. Since August 29, 2020, the virus has infected more than 24 million people and killed more than 841,000 .

At present, very few drugs have been effective in treating the disease, and no drug has been developed for definitive treatment $[2,3]$; the most important treatment for these patients is supportive care [4]. The first cause of death in these patients was acute respiratory failure syndrome (ARDS) [5], and the second reason has been found to be hyperinflammatory syndrome [6,7]. This complication is due to the high secretion of cytokines in relation to overactive immune response of the immune system, which leads to the multiple organ dysfunction syndromes, which may be the cause of acute respiratory failure. Hyperinflammatory syndrome is sometimes triggered by other viral infections in adults, with acute respiratory failure occurring in approximately $50 \%$ of cases [8].

According to recent findings, the characteristics of hemophagocytic lymphohistiocytosis are similar to the crit- ically ill patients with COVID-19; therefore, these 2 diseases may have a common treatment. The cytokines observed in the critically ill patients with COVID-19 are increased interleukin (IL)-1, IL-2, IL-6, IL-7, granulocyte colony-stimulating factor, interferon- $\gamma$ inducible protein 10 , monocyte chemoattractant protein 1 , macrophage inflammatory protein $1-\alpha$, and tumor necrosis factor- $\alpha[7$, 9-11]. A study also found that the patients who died of coronavirus had higher levels of ferritin and IL-6 than those who survived [5]. Therefore, the idea may come to mind that patient survival may increase by suppressing the immune system. However, as in the MERS outbreak corticosteroids were not used routinely, even though in the COVID-19 outbreak immunosuppressive drugs have been used in a limited way and the results have been acceptable, these drugs also have their own side effects, which may worsen the patient's condition $[6,12]$. Studies have also shown this hyperinflammatory syndrome can be prevented by IL-1 and IL- 6 blockade $[13,14]$. A metaanalysis study suggested a cutoff of more than $55 \mathrm{pg} / \mathrm{mL}$ of IL- 6 for identifying patients at high risk of severe COVID-19 and more than $80 \mathrm{pg} / \mathrm{mL}$ can be used for identifying patients at high risk of mortality [15].

Hemoadsorption is a method used to purify the blood and separate the substances. To this end, different car- karger@karger.com

(c) 2020 S. Karger AG, Basel

Karger"
Behnam Masmouei

School of Nursing Hazrat Zahra (P.B.U.H)

Bouali Boulevard

Abadeh City 7391983688 (Iran)

behnam.masmouei@gmail.com 


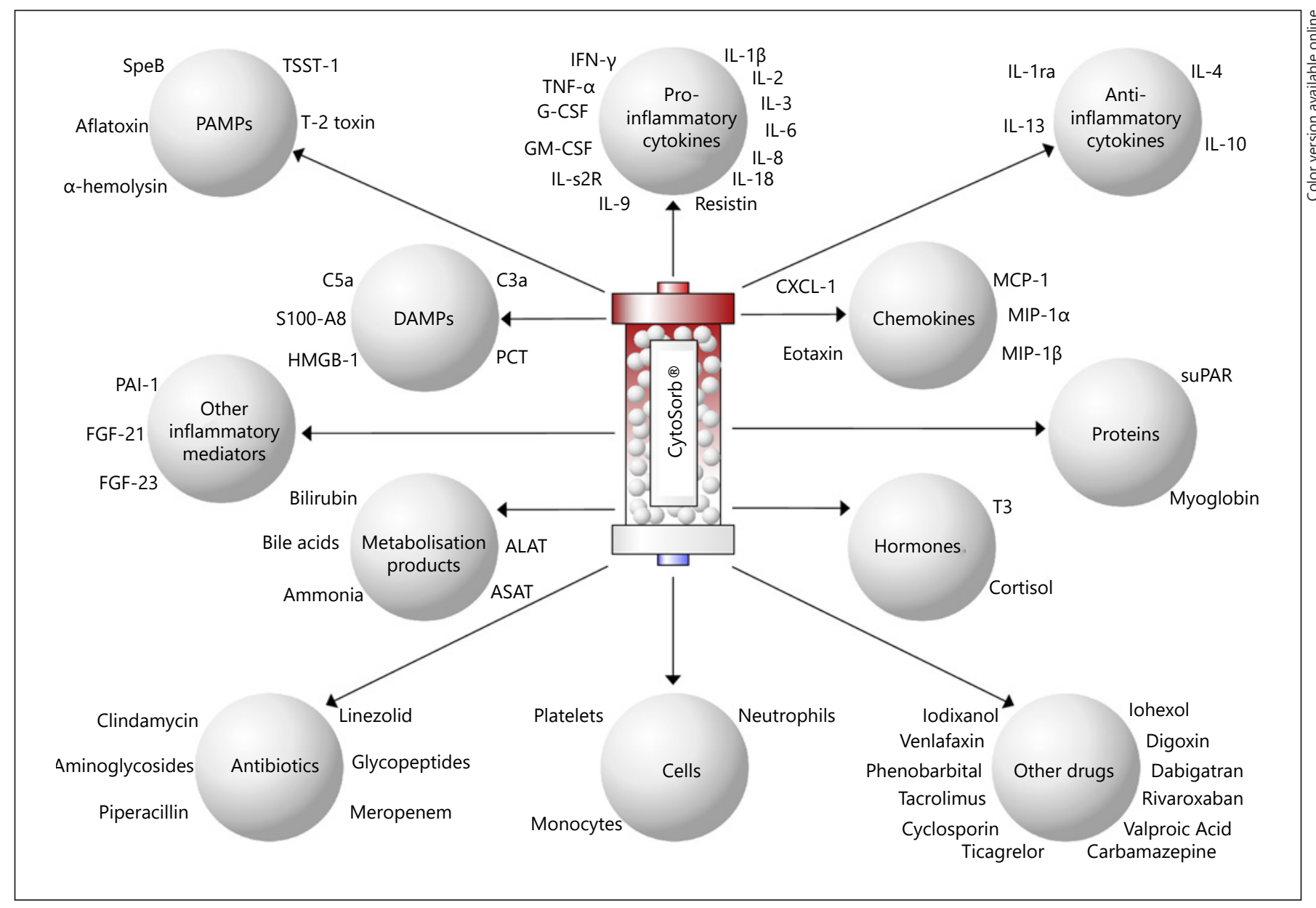

Fig. 1. Function of CytoSorb [photo was taken from Poli EC, Rimmele T, Schneider AG. Hemoadsorption with CytoSorb $^{\circledR}$. Intensive Care Med. 2019;45(2):236-9].

tridges are used, and the HA-330 type is designed to absorb the cytokines [16]. CytoSorb is a recent device designed to remove the cytokine from the blood using hemoadsorption. CytoSorbcartridgescontainbiocompatible polystyrene divinylbenzene copolymer beads capable of adsorbing the molecules of medium molecular weight using a combination of size exclusion and hydrophobic interactions [17]. CytoSorb can absorb a large number of inflammatory and pre-inflammatory factors and proteins [18] (Fig. 1).

In one study, the ability of this method to treat ARDS was confirmed [19]. However, this procedure is not without complications similar to other treatment methods, so removal of antibiotics and other beneficial molecules might lead to thrombocytopenia and leukopenia which are the side effects of hemoadsorption with CytoSorb [10].

CytoSorb Therapy in COVID
Based on the above-mentioned points, it is hypothesized that this treatment modality is effective in treating critically ill patients with COVID-19 with ARDS and hyperinflammatory syndrome by removing inflammatory factors from the plasma. To date, definitive criteria for initiating hemoadsorption with CytoSorb in COVID-19 critically ill patients have not been established. However, it seems that the start of this treatment cannot be decided solely by considering the clinical condition and acute respiratory failure; it requires confirmation of the relationship between the level of inflammatory factors and ARDS.

\section{Conflict of Interest Statement}

The authors report no declaration of interest. 


\section{Funding Sources}

The authors did not receive any funding.

\section{Author Contributions}

Behnam Masmouei: study design and drafting the final version. Mehdi Harorani and Mohammad-Rafi Bazrafshan: gathering information and checking the accuracy of studies. Zahra Karimi: writing the first draft.

\section{References}

1 Liu Y, Gayle AA, Wilder-Smith A, Rocklöv J. The reproductive number of COVID-19 is higher compared to SARS coronavirus. J Trav Med. 2020;27(2):taaa021.

2 Grein J, Ohmagari N, Shin D, Diaz G, Asperges E, Castagna A, et al. Compassionate use of remdesivir for patients with severe Covid-19. N Engl J Med. 2020 Jun 11;382(24):2327-36.

3 Wang M, Cao R, Zhang L, Yang X, Liu J, Xu $\mathrm{M}$, et al. Remdesivir and chloroquine effectively inhibit the recently emerged novel coronavirus (2019-nCoV) in vitro. Cell Res. 2020;30(3):269-71.

4 Phua J, Weng L, Ling L, Egi M, Lim C-M, Divatia JV, et al. Intensive care management of coronavirus disease 2019 (COVID-19): challenges and recommendations. Lancet Respir Med. 2020 May;8(5):506-17.

5 Ruan Q, Yang K, Wang W, Jiang L, Song J. Clinical predictors of mortality due to COVID-19 based on an analysis of data of $150 \mathrm{pa}-$ tients from Wuhan, China. Intensive Care Med. 2020 May;46(5):846-8.

6 Mehta P, McAuley DF, Brown M, Sanchez E, Tattersall RS, Manson JJ. COVID-19: consider cytokine storm syndromes and immunosuppression. Lancet. 2020 Mar 28;395(10229): $1033-4$.
7 Liu B, Li M, Zhou Z, Guan X, Xiang Y. Can we use interleukin-6 (IL-6) blockade for coronavirus disease 2019 (COVID-19)-induced cytokine release syndrome (CRS)? J Autoimmun. 2020 Jul;111:102452.

8 Seguin A, Galicier L, Boutboul D, Lemiale V, Azoulay E. Pulmonary involvement in patients with hemophagocytic lymphohistiocytosis. Chest. 2016;149(5):1294-301.

9 Huang C, Wang Y, Li X, Ren L, Zhao J, Hu Y, et al. Clinical features of patients infected with 2019 novel coronavirus in Wuhan, China. Lancet. 2020;395(10223):497-506.

10 Ankawi G, Xie Y, Yang B, Xie Y, Xie P, Ronco C. What have we learned about the use of $c y$ tosorb adsorption columns? Blood Purif. 2019;48(3):196-202.

11 Coperchini F, Chiovato L, Croce L, Magri F, Rotondi M. The Cytokine storm in COVID-19: an overview of the involvement of the chemokine/chemokine-receptor system. Cytokine Growth Factor Rev. 2020 Jun;53:2532.

12 Ritchie AI, Singanayagam A. Immunosuppression for hyperinflammation in COVID-19: a double-edged sword? Lancet. 2020 Apr 4;395(10230): 1111.

13 Cavalli G, De Luca G, Campochiaro C, DellaTorre E, Ripa M, Canetti D, et al. Interleukin-1 blockade with high-dose anakinra in patients with COVID-19, acute respiratory distress syndrome, and hyperinflammation: a retrospective cohort study. Lancet Rheumatol. 2020 Jun;2(6):e325-31.
14 Zhang C, Wu Z, Li J-W, Zhao H, Wang G-Q. The cytokine release syndrome (CRS) of severe COVID-19 and interleukin-6 receptor (IL-6R) antagonist tocilizumab may be the key to reduce the mortality. Int $J$ Antimicrob Agents. 2020 May;55(5):105954.

15 Aziz M, Fatima R, Assaly R. Elevated interleukin-6 and severe COVID-19: a meta-analysis. J Med Virol. 2020 Apr 28.

16 Ankawi G, Fan W, Pomarè Montin D, Lorenzin A, Neri M, Caprara C, et al. A new series of sorbent devices for multiple clinical purposes: current evidence and future directions. Blood Purif. 2019;47(1-3):94-100.

17 Malard B, Lambert C, Kellum JA. In vitro comparison of the adsorption of inflammatory mediators by blood purification devices. Intensive Care Med Exp. 2018;6(1):12.

18 Poli EC, Rimmelé T, Schneider AG. Hemoadsorption with CytoSorb. Intensive Care Med. 2019;45(2):236-9.

19 Kogelmann K, Scheller M, Drüner M, Jarczak D. Use of hemoadsorption in sepsis-associated ECMO-dependent severe ARDS: a case series. J Intensive Care Soc. 2020 May;21(2): $183-90$ 